Original Article

\title{
Size-dependent sex allocation in Solanum lycocarpum St. Hil. (Solanaceae)
}

\author{
Alocação de sexo dependente de tamanho em Solanum lycocarpum St. Hil. (Solanaceae)
}

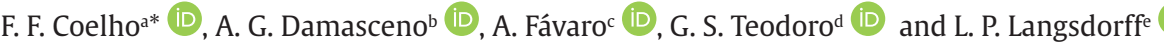 \\ anniversidade Federal de Lavras - UFLA, Departamento de Biologia, Setor de Botânica, Lavras, MG, Brasil \\ 'Universidade Federal de Lavras - UFLA, Departamento de Biologia, Programa de Pós-graduação em Genética, Lavras, MG, Brasil \\ 'Universidade Federal de Lavras - UFLA, Departamento de Biologia, Programa de Pós-graduação em Ecologia Aplicada, Lavras, MG, Brasil \\ dUniversidade Federal do Pará - UFPA, Instituto de Ciências Biológicas, Belém, PA, Brasil \\ eUniversidade Federal de Lavras - UFLA, Departamento de Biologia, Programa de Pós-graduação em Botânica Aplicada, Lavras, MG, Brasil
}

\begin{abstract}
Resource allocation to reproduction can change depending on size, as predicted by the size-dependent sex allocation. This theory is based on the fact that small individuals will invest in the allocation of sex with lower cost of production, usually male gender. In plants, there are some andromonoecy species, presence of hermaphrodite and male flowers in the same individual. Andromonoecy provides a strategy to optimally allocate resources to male and female function, evolving a reproductive energy-saving strategy. Thus, our objective was to investigate the size-dependent sex allocation in Solanum lycocarpum St. Hil. We tested the hypothesis that plants with larger size will invest in the production of hermaphrodite flowers, because higher individuals have greater availability of resources to invest in more complex structures involving greater energy expenditure. The studied species was S. lycocarpum, an andromonoecious species. From June 2016 to March 2017 the data were collected in 38 individuals, divided in two groups: the larger plant group $(n=18$; height=3-5 m) and the smaller plant group $(n=20$; height=1-2 $\mathrm{m}$ ).Our data show that there was effect of plant size on the flower production and the sexual gender allocation. The larger plants showed more flowers and higher production of hermaphrodite flowers. Furthermore, in the flower scale, we observed allometric relationship among the flower's traits with proportional investments in biomass, anther size and gynoecium size. Our results are in agreement with size-dependent sex allocation theory and andromonoecy hypothesis related to mechanisms for optimal resource allocation to male and female function.
\end{abstract}

Keywords: andromonoecy, biomass allocation, floral attributes, sex allocation, size-dependent gender.

\section{Resumo}

A alocação de recursos para reprodução pode mudar dependendo do tamanho, conforme previsto pela alocação sexual dependente do tamanho. Essa teoria é baseada no fato de que indivíduos pequenos investirão na alocação sexual com menor custo de produção, geralmente do sexo masculino. Nas plantas, existem algumas espécies andromonoicas, presença de hermafrodita e flores masculinas no mesmo indivíduo. A andromonoicia fornece uma estratégia para alocar recursos de maneira ideal às funções masculina e feminina, desenvolvendo uma estratégia reprodutiva de economia de energia. Assim, nosso objetivo foi investigar a alocação sexual dependente do tamanho em Solanum lycocarpum St. Hil. Testamos a hipótese de que plantas de maior tamanho investirão na produção de flores hermafroditas, pois indivíduos mais altos economizam mais disponibilidade de recursos para investir em estruturas mais complexas que envolvem maior gasto de energia. A espécie estudada foi S. lycocarpum, uma espécie andromonoica. De junho de 2016 a março de 2017, os dados foram coletados em 38 indivíduos, divididos em dois grupos: o maior grupo de plantas $(n=18$; altura $=3-5 \mathrm{~m})$ e o menor grupo de plantas $(\mathrm{n}=20$; altura = 1-2 m). Nossos dados mostram que houve efeito do tamanho da planta na produção de flores e na alocação sexual. As plantas maiores apresentaram mais flores e maior produção de flores hermafroditas. Além disso, observamos uma relação alométrica entre as características da flor, com investimentos proporcionais em biomassa, tamanho da antera e tamanho do gineceu. Nossos resultados estão de acordo com a teoria de alocação de sexo dependente de tamanho e a hipótese de andromonoicia relacionada a mecanismos para a alocação ótima de recursos para a função masculina e feminina.

Palavras-chave: andromonoicia, alocação de biomassa, atributos florais, alocação sexual, sexo dependente do tamanho.

*e-mail: flaviafcoelho@gmail.com

Received: May 4, 2020 - Accepted: August 19, 2020

This is an Open Access article distributed under the terms of the Creative Commons Attribution License, which permits unrestricted use, distribution, and reproduction in any medium, provided the original work is properly cited. 


\section{Introduction}

Plants have three essential functions: growth, defense against herbivores and reproduction, and each of these functions needs some resources (Weiner et al., 2009). However, the resources are limited and the essential functions compete for them, which generate a trade-off between the essential functions, leading to a resource differential allocation (Bazzaz et al., 1987), as plants are not able to invest simultaneously in growth, reproduction and defense (Weiner et al., 2009). Thus, these differences in resources allocation among different structures or activities are considered a process of partitioning (Weiner et al., 2009).

Sexual allocation is one type of allocation that may occurs in both animals and plants and has as premise that the individual can change his gender taking into account the energy expenditure, opting for the more favorable sex (Warner et al., 1975; Lloyd and Bawa, 1984; Warner, 1988; Vega-Frutis et al., 2014). This modification of the sexual gender will depend mainly on the resources available in the environment (Warner, 1988; Yakimowski and Barrett, 2014). Whether the resource is scarce, the sexual gender will be the one that demands less energy for the individual. In this way, the individual will tend to produce male gametes, which are usually smaller and more numerous in relation to female gametes. This last have a high energy cost to the plant (Warner, 1988). This allocation has been considered a survival strategy because it affects the plant fitness through the male and female functions (Cao and Kudo, 2008).

Another theory that can be linked to the gender change is the size-dependent sex allocation. This theory is based on the fact that small individuals will invest in the allocation of sex with lower cost of production, usually male gender (Lloyd and Bawa, 1984; VegaFrutis et al., 2014). Larger individuals will have greater availability of maternal resources and will become female. However, the sex allocation can be male-biased in larger plants of wind-pollinated species, such as Ambrosia artemisiifolia, and Pennisetum typhoides (Ackerly and Jasieński, 1990; Dajoz and Sandmeier, 1997). Thus, changes in sexual expression may occur throughout the life of the organism being associated with its increase or decrease in size (Bierzychudek, 1984; Schlessman, 1991; VegaFrutis et al., 2014; Zhang et al., 2014b). The increase in size is related to the improvements in the post-flowering resources of the plant, which can lead to an increase in female flowers (Lloyd and Bawa, 1984; Klinkhamer et al., 1997). The gender change size-dependent has led to many studies that provide a better understanding of the sexual ratios of flowers and the mechanisms of evolution of the reproductive systems in plants (Cao and Kudo, 2008; Barrett, 2010, 2013; J. Zhang et al., 2014a; Z. Q. Zhang et al., 2014b; Nakahara et al., 2018).

In some angiosperms exist a reproductive system that is called andromonoecy. In this sexual system, the individual has male and hermaphrodite flowers (VegaFrutis et al., 2014) that can be determinate by expression regulatory genes (Barrett, 2002; Charlesworth, 2002; Diggle et al., 2011; Ming et al., 2011), by epigenetic control
(Diggle et al., 2011; Zhang et al., 2014a) or by hormonal influence (Diggle et al., 2011; Zhang et al., 2014a). The hermaphrodite flowers, also called perfect flowers, have both male and female structures and usually they are bigger than male flowers (Diggle et al., 2011; Zhang et al., 2014b). The most studies about maintenance of andromonoecy support the hypothesis that the andromonoecy provides the mechanisms for optimal resource allocation to male and female function (Primack and Lloyd, 1980; Charnov, 1982; Huang, 2003).This hypothesis assumes that because female reproductive success is limited by resources, individual fitness will be enhanced by staminate flowers once female reproductive success is maximized, since the production of staminate flowers should be less costly than perfect flowers (Primack and Lloyd, 1980). According to Lloyd (1980), the sexual strategies to maximizing fitness from reproductive efforts expended during a sexual reproduction episode lead to a better understanding of the evolutionary history of a group. In this way, with this work, we obtained more information about this process and provided important information on aspects of evolutionary biology of the genus Solanum (Solanaceae family). Our goal was to investigate the size-dependent sex allocation in Solanum lycocarpum St. Hil. We also evaluated the allometric relationship among floral parts. This species is andromonoecious; its flowers are pentamerous, of lilac color and blooms the whole year, having a peak of flowering in rainy periods (OliveiraFilho and Oliveira, 1988; Moura et al., 2010; Feliciano and Salimena, 2011). We tested the hypothesis that plants with larger size will produce more flowers than small plants. In addition, large plants will invest more in hermaphrodite flowers than small plants, because higher individuals have greater availability of resources to invest in more complex structures involving greater energy expenditure.

\section{Materials and Methods}

\subsection{Study area}

This study was conducted in a pasture area at Universidade Federal de Lavras, within biome Cerrado, in Minas Gerais state. The study area was defined by geographic coordinate $21^{\circ} 13^{\prime} 47.4^{\prime \prime} \mathrm{S}$ e $44^{\circ} 5754.3^{\prime \prime} \mathrm{W}$. Lavras climate is classified as Cwb on Köppen climate classification (Dias et al., 2002). The average altitude is around $918 \mathrm{~m}$, the annual average precipitation in Lavras region is $1529 \mathrm{~mm}$ and the average temperature is $19.5^{\circ} \mathrm{C}$ (Dantas et al., 2007; Dias et al., 2002). The soil is poor in essential nutrients, acid, deep and with aluminum toxicity (Furley and Ratter, 1988).

\subsection{Studied system}

The species Solanum lycocarpum St. Hil. (Solanaceae) is a shrub, characteristic to Brazilian Cerrado and commonly found in roadsides, open lands and pastures. It is known as Wolf s Plant or Wolf's Apple, reaching up to five meters high, its crown is rough and thin with fragile branches (Oliveira-Filho and Oliveira, 1988). This plant is resistant, being able to tolerate dry climates, fire and long 
droughts. Besides that, S. lycocarpum grows and develops in unfavorable environmental conditions, as acidic soils, poor in nutrients (Malves and Coelho, 2015). This species blooms during all months of the year, although the number of open flowers and inflorescences rises in rainy periods (Oliveira-Filho and Oliveira, 1988). The flowers of $S$. lycocarpum are andromonoecious, in other words, in the same individual exist male flowers and hermaphrodite flowers (Oliveira-Filho and Oliveira 1988). The fruit production occurs during all year too, but is more frequent in February (Oliveira-Junior et al., 2003). The fruits have numerous seeds with high germination rate and rapid emergence (Vasconcelos et al., 2009). Furthermore, this species may present galls, which cause negative impacts on plants, decreasing growth, biomass and production of flowers and fruits (Price et al.,1987; Malves and Coelho 2015; Prade et al., 2016).When galls are present, biomass and size of flowers can be affected and flower production can decrease in approximately four times (Malves and Coelho, 2015).

\subsection{Field data}

From June 2016 to March 2017, we did five field excursions. The data were collected from a natural population of $S$. lycocarpum with 38 individuals, which were divided in two groups: the larger plant group $(n=18)$ with height sampled varying from 3 to $5 \mathrm{~m}$ and the smaller plant group ( $\mathrm{n}=20$ ) with individuals varying from 1 to $2 \mathrm{~m}$ in height. In each group, the individuals were tagged with numbered plastic plates.

In each visit, we collected a maximum of 15 flowers, randomly, per individual marked, which were collected with a tool for clipping, in small individuals, and with a trimmer in larger individuals. After collection, the flowers were taken to the laboratory. We quantify the number of flowers per category and sexual gender belonging as i) hermaphrodites (Figure 1A) or ii) male (Figure 1B). After that, a flower of each gender was selected per individual in which the following floral attributes were measured with a pachymeter: i) length of corolla, ii) fillet size, iii) anther size and, iv) ovary size (diameter $\mathrm{x}$ height). The flowers were dried at $80^{\circ} \mathrm{C}$ for 30 hours and the dry mass was then measured.

\subsection{Data analysis}

In order to verify if individuals of the larger plant group produced a higher total of flowers than the individuals of the smaller plant group, as well as if larger plants produce independently more male and hermaphrodite flowers than small plants was applied the Mann-Whitney test.

To analyze whether flower gender influenced floral attributes, anther size and total biomass of flower and if was interaction between the attributes: total biomass of flower versus anther size, diameter of corolla versus anther size, height of the gynoecium versus anther size and height of the gynoecium versus ovary, we used generalized linear mixed model (GLMM).

All analyses were carried out in SYSTAT version 12.

\section{Results}

The production of flower appeared to be closely linked to plant size, since the number of flowers was significantly greater in plants from the larger group than in plants from lower group $(U=308.000 ; p<0.001$ ) (Figure 2). Larger plants produced 540 flowers, more than twice as many as small plants that produced 213 flowers in total. They produced a greater number of both male flowers $(\mathrm{U}=302.500 ; \mathrm{p}<0,001)$, and hermaphrodite flowers $(\mathrm{U}=254.500 ; \mathrm{p}=0,018)$ (Figure 3).

The flower gender did not influence the anther size $(\mathrm{F}=0.041, \mathrm{p}=0.52)$ (Figure $4 \mathrm{~A})$ and the total biomass of flower $(\mathrm{F}=0.67, \mathrm{p}=0.68)$ (Figure $4 \mathrm{~B})$. However, flowers with a greater diameter of corolla had a greater anther size $(\mathrm{F}=33.55, \mathrm{p}<0.001)$ (Figure $4 \mathrm{~A})$.

The anther size increased with the flower biomass (Figure 4B). There was a significant relationship between the total biomass of flower and anther size $\left(r^{2}=0.22, F=20.26\right.$, $\mathrm{p}<0.001$ ).We also found a significant relationship between the gynoecium size and anther size (Figure 5A). Flowers with higher anther had a larger gynoecium $\left(r^{2}=0.22\right.$, $\mathrm{F}=7.64, \mathrm{p}=0.01$ ). However, there were no significant relationships between the diameter of corolla and anther size $\left(\mathrm{r}^{2}=0.3, \mathrm{~F}=0.81, \mathrm{p}=0.37\right)$ (Figure $4 \mathrm{~A}$ ), and between height of the gynoecium and ovary size $\left(r^{2}=0.025, F=0.69\right.$, $\mathrm{p}=0.41$ ) (Figure 5B).
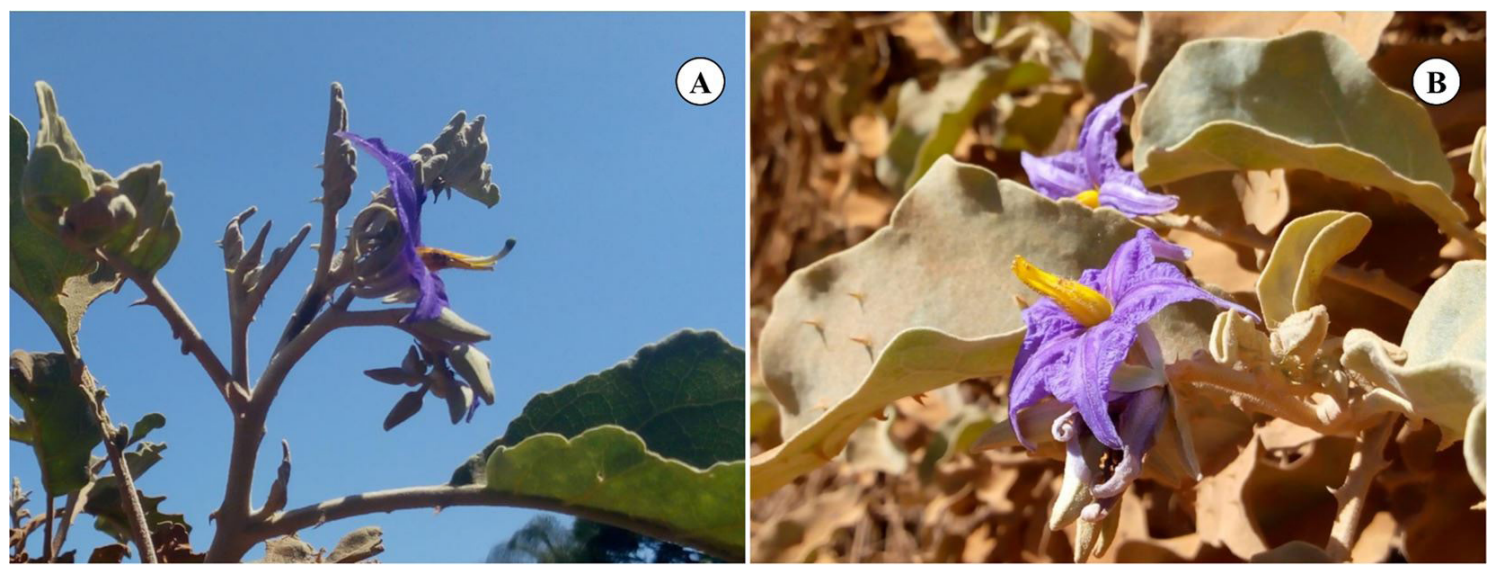

Figure 1. Flowers of Solanum lycocarpum. (A) Hermaphrodite flower; (B) Male flowers. The scale bars units were $3 \mathrm{~cm}$ for each picture. 


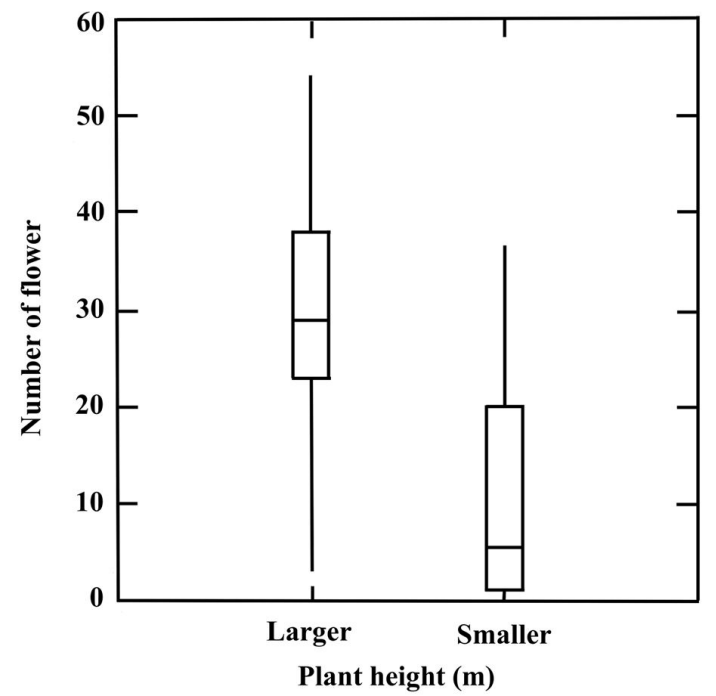

Figure 2. Number of flowers per plant as a function of the plant size. The number of flowers in smaller group $($ minimum $=0.000$; maximum $=36.00 ;$ mean $=5 ;$ median $=10.6$; standard error $=2.54$; versus in larger group $($ minimum $=3.00$; maximum $=54.00$; mean $=29.00$; median $=30.00 ;$ standard error $=3.51$ ).

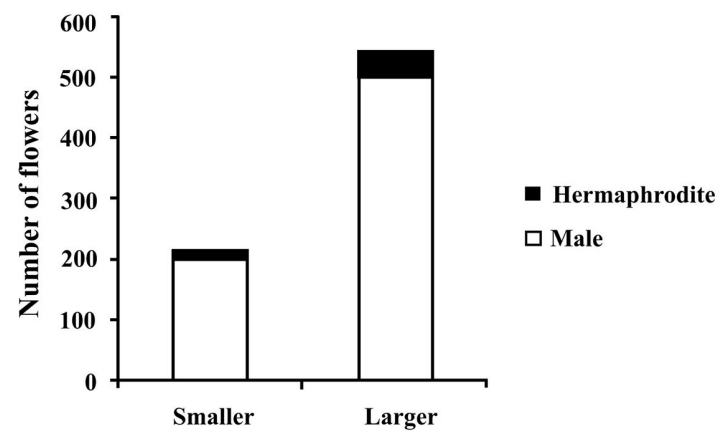

Figure 3. Proportion of male and hermaphrodite flowers as a function of plant size (small group versus large group).

\section{Discussion}

Our data showed more investments in flower production in larger Solanum individuals. They are consistent with Warner (1988) prediction that larger individuals possess more resources and can allocate more of them for reproduction. On the other hand, smaller individuals tend to invest more in vegetative growth (Warner, 1988). Similar result was found by Cao and Worley (2013), in a study carried out with two species of the genus Cardiocrinum, which showed that the species that presents larger individuals produces more flowers, once the biomass allocation can be limited by architectural restrictions, and these changes with the plant size (Bartušková et al., 2015). Thus, in this perspective, the allocation for reproductive functions is dependent on canopy size (Müller et al., 2000).

The higher number of flowers has an important ecological and evolutionary role, as this can increases the chances of pollination, fecundation and seed dispersal (Valenta et al., 2017). Conner et al. (1995) showed that the increase in flowers number was determinant to increase the number of pollinator visits. Thus, we can expect that the higher number of flowers in larger individuals can enhance pollinator attraction and facilitate flower handling and pollen deposition (Valenta et al., 2017).

Our data also showed that there was a strong effect of plant size on the flower production and the sexual gender allocation, corroborant our prediction. The larger plants showed a higher production of hermaphrodite flowers, being in the agreement with "size-dependent sex allocation" theory and andromonoecy hypothesis related to mechanisms for optimal resource allocation to male and female function. According to the theory of size-dependent sex allocation, larger individuals have more energy to spend in structures that demand more energy, such as the hermaphrodite flowers (Lloyd and Bawa, 1984; Vega-Frutis et al., 2014). However, the theory of size-dependent sex allocation does not always have a clear pattern for all plant species. For example, Liliumapertum (Liliaceae) showed similar result as we found, in which

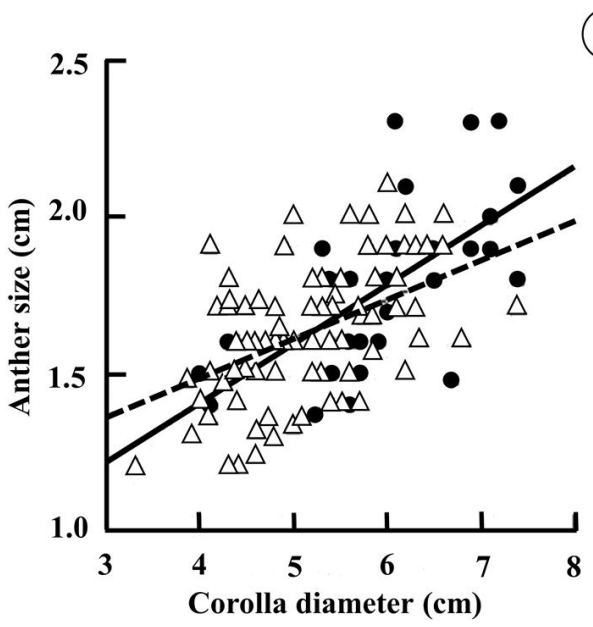

(A)

Figure 4. Interaction between the floral attributes according to the flowers gender. The circles represent hermaphrodite flowers and the squares represent male flowers. (A) Corolla diameter $(\mathrm{cm})$ versus anther size $(\mathrm{cm})$; (B) Flower Biomass versus anther size $(\mathrm{cm})$. 

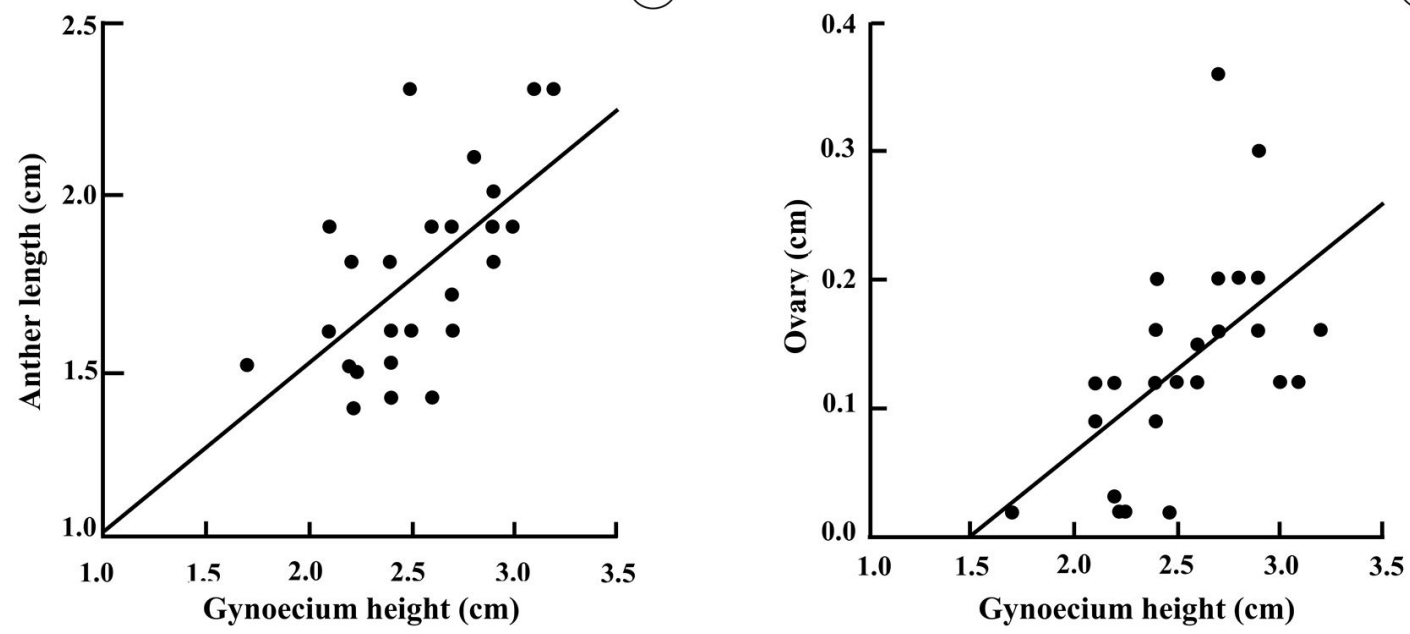

Figure 5. Interaction between the floral attributes in hermaphrodite flowers. (A) Gynoecium height ( $\mathrm{cm}$ ) versus anther length (cm); (B) Gynoecium height $(\mathrm{cm})$ versus ovary $(\mathrm{cm})$.

they verified a significant increase in hermaphrodite flowers with increase of plant size (Zhang et al., 2014b). Meanwhile, Nakahara et al., (2018) observed an opposite pattern, with larger plants producing more male flowers in Ambrosia artemisiifolia. This, according to the authors, occurred because the species is pollinized by wind. Thus, high plants bearing more male flowers facilitate the pollen dispersion. Our studied species is pollinated mainly by bees (Oliveira-Filho and Oliveira, 1988) and, in this case, hermaphrodite flowers can be advantageous. On the other hand, in Solanum houstonii the number of hermaphrodite and staminate flowers was not related to the plant size (Carbonell, 2019).

The fact of larger S. lycocarpum showed a higher proportion of hermaphrodite flowers is also supported by the andromonoecy hypothesis that is based in resource reallocation hypothesis (Vega-Frutis et al., 2014). Andromonoecy provides a strategy to optimally allocate resources to male and female function, evolving a reproductive energy-saving strategy (VegaFrutis et al., 2014). Thus, individuals can save energy producing male flowers and the resources saved can be reallocated towards fitness-enhancing traits of both male and female function (Bertin, 1982; Vega-Frutis et al., 2014). Recently, Carbonell, (2019) showed that Solanum houstonii produced a relatively low proportion of hermaphrodite flowers (two hermaphrodite flowers per eight male flowers) in an apparently fixed pattern of sex expression, with no changes in proportion of hermaphrodite flowers with the plant size. In our study, we observed changes in proportion of flowers with size, indicating that this can be a plastic response of S. lycocarpum.

Considering the investments to produce individual flowers, the flower sex did not influence the anther size and the total biomass of flower in S. lycocarpum. In the same way, S.houstonii did not showed differences in flower size (Carbonell, 2019). This absence of differences between flower genders can be related to the importance of male flowers, as staminate flowers increase pollinator attraction as some staminate flowers are preferred by pollinators or donate more pollen that reaches the stigma than hermaphrodite flowers (Bertin, 1982; Luo et al., 2012; Anderson et al., 2015; Carbonell, 2019). We also observed allometric relationship among the flower's traits evaluated that indicates the proportional energy investments to build the flowers (Weiner et al., 2009).

Thus, we concluded that the size of S. lycocarpum influences the sexual allocation and this seems to be a plastic response in this species. The andromonoecy also is related with plant size, indicating that larger individuals can have more energy to invest to produce hermaphrodite flowers, in which has an important ecology and evolutionary role.

\section{Acknowledgements}

The authors are grateful to UFLA for the sampling permit. We also are grateful the lab colleagues for their help in the field.

\section{References}

ACKERLY, D.D. and JASIEŃSKI, M., 1990. Size- dependent variation of gender in high density stands of the monoecious annual, Ambrosia artemisiifolia (Asteraceae). Oecologia, vol. 82, no. 4, pp. 474-477. http://dx.doi.org/10.1007/BF00319788. PMid:28311470.

ANDERSON, G.J., BERNARDELLO, G. and SANTOS-GUERRA, A., 2015. Reproductive biology of Solanum vespertilio (Solanaceae), a zygomorphic, heterantherous, enantiostylous, and andromonoecious rare Canary Islands endemic. Plant Systematics and Evolution, vol. 301, no. 4, pp. 1191-1206. http://dx.doi. org/10.1007/s00606-014-1143-4. 
BARRETT, S.C., 2013. The evolution of plant reproductive systems: how often are transitions irreversible? Proceedings of the Royal Society B: Biological Sciences, vol. 280, no. 1765, pp. 20130913. http://dx.doi.org/10.1098/rspb.2013.0913.

BARRETT, S.C.H., 2002. The evolution of plant sexual diversity. Nature Reviews. Genetics, vol. 3, no. 4, pp. 274-284. http:// dx.doi.org/10.1038/nrg776. PMid:11967552.

BARRETT, S.C.H., 2010. Understanding plant reproductive diversity. Philosophical Transactions of the Royal Society of London. Series B, Biological Sciences, vol. 365, no. 1537, pp. 99-109. http://dx.doi. org/10.1098/rstb.2009.0199. PMid:20008389.

BARTUŠKOVÁ, A., DOLEŽAL, J., JANEČEK, Š., LANTA, V. and KLIMEŠOVÁ, J., 2015. Changes in biomass allocation in species rich meadow after abandonment: ecological strategy or allometry? Perspectives in Plant Ecology, Evolution and Systematics, vol. 17, no. 5, pp. 379-387. http://dx.doi. org/10.1016/j.ppees.2015.06.003.

BAZZAZ, F.A., CHIARIELLO, N.R., COLEY, P.D. and PITELKA, L.F., 1987. Allocating resources to reproduction and defense. BioScienc, vol. 37, no. 1, pp. 58-67. http://dx.doi.org/10.2307/1310178.

BERTIN, R.I., 1982. The evolution and maintenance of andromonoecy. Evolutionary Theory, vol. 6, pp. 25-32.

BIERZYCHUDEK, P., 1984. Determinants of gender in Jack-in-thepulpit: the influence of plant size and reproductive history. Oecologia, vol. 65, no. 1, pp. 14-18. http://dx.doi.org/10.1007/ BF00384456. PMid:28312103.

CAO, G.X. and KUDO, G., 2008. Size-dependent sex allocation in a monocarpic perennial herb, Cardiocrinum cordatum (Liliaceae). Plant Ecology, vol. 194, no. 1, pp. 99-107. http:// dx.doi.org/10.1007/s11258-007-9277-x.

CAO, G.X. and WORLEY, A.C., 2013. Life history trade-offs and evidence for hierarchical resource allocation in two monocarpic perennials. Plant Biology, vol. 15, no. 1, pp. 158165. http://dx.doi.org/10.1111/j.1438-8677.2012.00612.x. PMid:22672109.

CARBONELL, A.K.Z., 2019. Expression and functional significance of andromonoecy in Solanum houstonii. Stirling: University of Stirling, 175 p. Tese de Doutorado em Filosofia.

CHARLESWORTH, D., 2002. Plant sex determination and sex chromosomes. Heredity, vol. 88, no. 2, pp. 94-101. http://dx.doi. org/10.1038/sj.hdy.6800016. PMid:11932767.

CHARNOV, E.L., 1982. The theory of sex allocation. Princeton: Princeton University Press. 355 p.

CONNER, J.K., DAVIS, R. and RUSH, S., 1995. The effect of wild radish floral morphology on pollination efficiency by four taxa of pollinators. Oecologia, vol. 104, no. 2, pp. 234-245. http:// dx.doi.org/10.1007/BF00328588. PMid:28307360.

DAJOZ, I. and SANDMEIER, M., 1997. Plant size effects on allocation to male and female functions in pearl millet, a hermaphroditic wind-pollinated species. Canadian Journal of Botany, vol. 75, no. 2, pp. 228-235. http://dx.doi.org/10.1139/b97-024.

DANTAS, A.A.A., CARVALHO, L.D. and FERREIRA, E., 2007. Classificação e tendências climáticas em Lavras, MG. Ciência e Agrotecnologia, vol. 31, no. 6, pp. 1862-1866. http://dx.doi.org/10.1590/S141370542007000600039 .

DIAS, H.C.T., FIGUEIRA, M.D., SILVEIRA, V., FONTES, M.A.L., OLIVEIRA-FILHO, A.D. and SCOLFORO, J.R.S., 2002. Variação temporal de nutrientes na serapilheira de um fragmento de floresta estacional semidecidual montana em Lavras, MG. Cerne, vol. 8, no. 2, pp. 1-16. http://dx.doi.org/10.1016/j. tig.2011.05.003.
DIGGLE, P.K., DI STILIO, V.S., GSCHWEND, A.R., GOLENBERG, E.M., MOORE, R.C., RUSSELL, J.R. and SINCLAIR, J.P., 2011. Multiple developmental processes underlie sex differentiation in angiosperms. Trends in Genetics, vol. 27, no. 9, pp. 368-376. http://dx.doi.org/10.1016/j.tig.2011.05.003. PMid:21962972.

FELICIANO, E.A. and SALIMENA, F.R.G., 2011. Solanaceae na Serra Negra, Rio Preto, Minas Gerais. Rodriguésia, vol. 62, no. 1, pp. 55-76. http://dx.doi.org/10.1590/2175-7860201162105.

FURLEY, P.A. and RATTER, J.A., 1988. Soil resources and plant communities of the central Brazilian cerrado and their development. Journal of Biogeography, vol. 15, no. 1, pp. 97-108. http://dx.doi.org/10.2307/2845050.

HUANG, S.Q., 2003. Flower dimorphism and the maintenance of andromonoecy in Sagittariaguyanensis sp. lappula (Alismataceae). The New Phytologist, vol. 157, no. 2, pp. 357-364. http://dx.doi.org/10.1046/j.1469-8137.2003.00676.x.

KLINKHAMER, P.G., DE JONG, T.J. and METZ, H., 1997. Sex and size in cosexual plants. Trends in Ecology \& Evolution, vol. 12, no. 7, pp. 260-265. http://dx.doi.org/10.1016/S0169-5347(97)01078-1. PMid:21238063.

LLOYD, D.G., 1980. Sexual strategies in plants III.A quantitative method for describing the gender of plants. New Zealand Journal of Botany, vol. 18, no. 1, pp. 103-108. http://dx.doi.org/10.1080 /0028825X.1980.10427235.

LLOYD, D.G. and BAWA, K.S., 1984. Modification of the gender of seed plants in varying conditions. Evolutionary Biology, vol. 17, no. 1, pp. 255-338.

LUO, Z.L., CHEN, S. and ZHANG, D.X., 2012. Floral reward presentation favored the expression of male function in the pollen-only flower Melastoma malabathricum. Journal of Systematics and Evolution, vol. 50, no. 6, pp. 488-495. http://dx.doi.org/10.1111/j.17596831.2012.00213.x.

MALVES, K. and COELHO, F.D.F., 2015. Gall influence on flower production in Solanum lycocarpum (Solanaceae). Pakistan Journal of Botany, vol. 47, no. 2, pp. 731-734.

MING, R., BENDAHMANE, A. and RENNER, S.S., 2011. Sex chromosomes in land plants. Annual Review of Plant Biology, vol. 62, no. 1, pp. 485-514. http://dx.doi.org/10.1146/annurevarplant-042110-103914. PMid:21526970.

MOURA, T.M., OLIVEIRA, G.C.X. and CHAVES, L.J., 2010. Correlação entre floração, frutificação e variáveis ambientais em Solanumn lycocarpum A. St. Hil, Solanaceae. Bioscience Journal, vol. 26, no. 3, pp. 457-462.

MÜLLER, I., SCHMID, B. and WEINER, J., 2000. The effect of nutrient availability on biomass allocation patterns in 27 species of herbaceous plants. Perspectives in Plant Ecology, Evolution and Systematics, vol. 3, no. 2, pp. 115-127. http://dx.doi. org/10.1078/1433-8319-00007.

NAKAHARA, T., FUKANO, Y., HIROTA, S.K. and YAHARA, T., 2018. Size advantage for male function and size-dependent sex allocation in Ambrosia artemisiifolia, a wind-pollinated plant. Ecology and Evolution, vol. 8, no. 2, pp. 1159-1170. http://dx.doi. org/10.1002/ece3.3722. PMid:29375787.

OLIVEIRA JUNIOR, E.N. SANTOS, C.D., ABREU, C.M.P., CORRÊA, A.D. and SANTOS, J.Z.L., 2003. Análise nutricional da fruta-de-lobo (Solanum lycocarpum St. Hil.) durante o amadurecimento. Ciência e Agrotecnologia, vol. 27, no. 4, pp. 846-851. http:// dx.doi.org/10.1590/S1413-70542003000400016.

OLIVEIRA-FILHO, A.D. and OLIVEIRA, L.D.A., 1988. Biologia floral de uma população de Solanum lycocarpum St. Hil. (Solanaceae) em Lavras, MG. Revista Brasileira de Botanica. Brazilian Journal of Botany, vol. 11, no. 1, pp. 23-32. 
PRADE, P., DIAZ, R., VITORINO, M.D., CUDA, J.P., KUMAR, P., GRUBER, B. and OVERHOLT, W.A., 2016. Galls induced by Calophyalatiforceps (Hemiptera: Calophyidae) reduce leaf performance and growth of Brazilian peppertree. Biocontrol Science and Technology, vol. 26, no. 1, pp. 23-34. http://dx.doi.org/10.1080/09583157 2015.1072131

PRICE, P.W., FERNANDES, G.W. and WARING, G.L., 1987. Adaptive nature of insect galls. Environmental Entomology, vol. 16, no. 1, pp. 15-24. http://dx.doi.org/10.1093/ee/16.1.15.

PRIMACK, R.B. and LLOYD, D.G., 1980. Andromonoecy in the New Zealand montane shrub manuka, Leptospermum scoparium (Myrtaceae). American Journal of Botany, vol. 67, no. 3, pp. 361-368. http://dx.doi.org/10.1002/j.1537-2197.1980.tb07661.x.

SCHLESSMAN, M.A., 1991. Size, gender, and sex change in dwarf ginseng, Panax trifolium (Araliaceae). Oecologia, vol. 87, no. 4, pp. 588-595. http://dx.doi.org/10.1007/BF00320425. PMid:28313704.

VALENTA, K., NEVO, O., MARTEL, C. and CHAPMAN, C.A., 2017. Plant attractants: integrating insights from pollination and seed dispersal ecology. Evolutionary Ecology, vol. 31, no. 2, pp. 249-267. http://dx.doi.org/10.1007/s10682-016-9870-3.

VASCONCELOS, P.B., PAULA, C.L. and VASCONCELOS, H.L., 2009. Resposta morfológica de Solanum lycocarpum aos efeitos da herbivoria e estresse hídrico. Horizonte Científico, vol. 3, no. 1, pp. 1-17.

VEGA-FRUTIS, R., MACÍAS-ORDÓÑEZ, R., GUEVARA, R. and FROMHAGE, L., 2014. Sex change in plants and animals: a unified perspective. Journal of Evolutionary Biology, vol. 27, no. 4, pp. 667-675. http://dx.doi.org/10.1111/jeb.12333. PMid:24779048.
WARNER, R.R., 1988. Sex change and the size-advantage model. Trends in Ecology E Evolution, vol. 3, no. 6, pp. 133-136. http://dx.doi.org/10.1016/0169-5347(88)901760. PMid:21227182.

WARNER, R.R., ROBERTSON, D.R. and LEIGH JUNIOR, E.G., 1975. Sex change and sexual selection. Science, vol. 190, no. 4215, pp. 633-638. http://dx.doi.org/10.1126/science.1188360. PMid:1188360.

WEINER, J., CAMPBELL, L.G., PINO, J. and ECHARTE, L., 2009. The allometry of reproduction within plant populations. Journal of Ecology, vol. 97, no. 6, pp. 1220-1233. http://dx.doi. org/10.1111/j.1365-2745.2009.01559.x.

YAKIMOWSKI, S.B. and BARRETT, S.C.H., 2014. Variation and evolution of sex ratios at the northern range limit of a sexually polymorphic plant. Journal of Evolutionary Biology, vol. 27, no. 7, pp. 1454-1466. http://dx.doi.org/10.1111/jeb.12322. PMid:24506681.

ZHANG, J., BOUALEM, A., BENDAHMANE, A. and MING, R., 2014a. Genomics of sex determination. Current Opinion in Plant Biology, vol. 18, pp. 110-116. http://dx.doi.org/10.1016/j.pbi.2014.02.012. PMid:24682067.

ZHANG, Z.Q., ZHU, X.F., SUN, H., YANG, Y.P. and BARRETT, S.C., 2014b. Size-dependent gender modification in Lilium apertum (Liliaceae): does this species exhibit gender diphasy? Annals of Botany, vol. 114, no. 3, pp. 441-453. http://dx.doi.org/10.1093/ aob/mcu140. PMid:25062885. 